\title{
ASSESSMENT OF SHELF LIFE AND BACTERIAL LOAD OF VIABLE EGGS OBTAINED AT THE POINT OF LAY FROM ROOM AND REFRIGERATOR STORAGE TEMPERATURES
}

\author{
Okafor-Elenwo, E. J., iD Enaigbe, A. A., iD *Akpoka, O. A. ID \\ Address (es): \\ Department of Biological Sciences, College of Applied and Natural Sciences, Igbinedion University, Okada, Nigeria. \\ *Corresponding author: ausbones@gmail.com
}

\section{ABSTRACT}

It is well established that storing hatching eggs over a longer period of time affects its quality. The current study evaluated the impact of egg storage duration in-relation to two different temperature conditions (room and refrigerator) to determine the bacterial load and shelf life of viable eggs. One hundred and twenty eggs were used for this study, 60 were boiled and 60 were raw. Thirty of the boiled eggs were stored at room temperature and the other 30 eggs were kept in the refrigerator. Similarly, 30 raw eggs were each stored at room and optimal refrigeration temperatures for eggs $\left(<7{ }^{\circ} \mathrm{C}\right)$ respectively, while the egg weight, viability and sensory tests were performed daily on the eggs. However, the eggs kept in the refrigerator were viable for longer and relatively maintained higher physical appearance and sensory quality compared to eggs kept at room temperature. In the investigation of bacterial load, the total viable count ranged from $6.0 \times 10^{3}$ to $11.9 \times 10^{3}$ coliform forming unit per millilitre (cfu/ml) and $1.0 \times 10^{3}$ to $6.5 \times 10^{3} \mathrm{cfu} / \mathrm{ml}$ for the boiled eggs kept at room and refrigeration temperatures (BRT and BFT) respectively. More so, the bacterial counts in raw eggs obtained at room and refrigerator storage ranged from $4.8 \times 10^{3}$ to $6.5 \times 10^{3} \mathrm{cfu} / \mathrm{ml}$. Subsequently, the characterization and identification of bacterial isolates indicated the presence of Salmonella pullorum, Proteus mirabilis and Pseudomonas sp. The Salmonella pullorum was isolated from all the egg samples (BRT, BFT, RRT and RFT). The Proteus mirabilis was isolated from boiled eggs kept in both room and refrigerator temperatures (BRT and BFT) while Pseudomonas sp. was obtained only from raw eggs stored in the refrigerator (RFT). In addition, the boiled eggs at room temperature started deterioration on Day 9 , while its counterpart in the refrigerator began spoilage or decrease in quality from Day 16 . The weight of the viable eggs in relation to the non-viable ones was statistically significant $(\mathrm{P}<0.05)$. The refrigeration of eggs increases its longevity while proper hygiene and adequate boiling of eggs reduces the risk of acquiring infections through bacterial contamination.

Keywords: Egg shelf life, bacterial load, refrigerator storage temperatures, room temperatures

\section{INTRODUCTION}

The chicken egg is a perfect source of proteins, lipids, essential vitamins, and minerals that are nutritionally and medically beneficial to humans. It is therefore essential that the eggs are in perfect health conditions, devoid of contaminants at the point of lay to maintain their potential viability status. However, some factors have been reported to be responsible for egg spoilage after it had been hatched or laid (Davies \& Breslin, 2002).

The outer layer of the egg known as the shell prevents microbial activity from penetrating the egg contents, moisture from escaping and to protect the egg during handling and transport. The bacteria at the surface are able to gain access through the pores of the shell to infect the inner part of the egg. Though the egg shell serves as physical barrier, the albumen (egg white) and yolk also contain anti-microbial properties such as protein components of Lysozyme and immunoglobulin Y (IgY) (a class of proteins formed by the immune system in reaction to certain foreign substances, and specifically able recognize them). These constituents are very effective during early stages of embryo development and to resist invasion and growth of microorganisms (Barnhart et al., 1991).

Despite the egg's innate properties to protect itself from bacterial attack, these barriers are transient and offer no permanent protection against the infiltration of bacteria through the shell and pores of the membrane. This results in formation of sliminess, jellying of albumen, offensive and pungent smell due to enzymatic, proteolytic and lypolytic substances released during bacterial growth (Moore \& Madden, 1993). The egg shell can readily be infected when passing through the vent and contamination occurs through the cloaca area within a short duration of lay and from contact with dirty surfaces. Previous research has shown chicken eggs to be associated with the transmission of human pathogenic bacteria such as Escherichia coli, Salmonella typhi, Listeria monocytogens and Yersinia enteriticus in human populations (Padron, 2005). Davies and Breslin (2002) emphasized the need to remove any contaminant on the surfaces of eggs to reduce the risk of bacterial adhesion and entry into the egg contents. His proposed ways of achieving this were washing, boiling water, hydrogen peroxide application, storage in refrigeration temperature and pasteurization. The aim of this study therefore was to evaluate the bacterial counts of viable eggs obtained at the point of lay from room and refrigerator storage temperatures.

\section{MATERIALS AND METHODS}

\section{Study Area}

The study was carried out in Okada community, Ovia North-East Local Government Area, Edo State, Nigeria.

\section{Sample Collections}

The egg samples were collected from Fortune poultry farm located at Iguomo quarter in Okada town. The farm holds about two thousand $(2,000)$ chicken layers, which were raised in cages, fed with Top Feed layer's match and supplemented with calcium bone meal (CBM). One hundred and eighty browncoloured eggs were collected in sterile plastic crates and immediately transported to the microbiology laboratory, Igbinedion University, Okada for analysis.

\section{Viability Test}

A Candler made of carton with inserted bright light was used for the viability testing of the egg samples and carried out in the dark in order to obtain a clearer observation of the internal features of the egg. A score which ranges from 0 to 5 was allotted on quality or viable basis. The viable eggs with intact quality were scored 5 and decreased down to 0 for non-viable with irritating, pungent smell.

\section{Measurement of Egg Weight}

The egg weight was measured using an electronic weighing balance (Adventurer Ohaus Company, Model XP 1005. NJ. (USA) to get the initial weight of the samples. Sixty egg samples consisting of both 30 boiled eggs using a cooking pot and 30 raw eggs were weighed and recorded

\section{Storage Procedure}

The egg samples were divided into 4 portions; the 30 boiled eggs and 30 raw eggs were packaged on plastic crates and each was stored at room $\left(28 \pm 2{ }^{\circ} \mathrm{C}\right)$ and refrigerator temperatures $\left(4 \pm 2{ }^{\circ} \mathrm{C}\right)$ respectively. The samples were analysed for bacterial load at interval of 5 days for a period of 45 days. 


\section{Isolation and Enumeration of Bacteria}

Isolation of bacteria from the egg samples was conducted by standard techniques of pour plating using nutrient agar and MacConkey agar following serial dilution of egg sample prepared from 1.0 up to $10^{-4} \mathrm{ml}$. Thereafter, $1.0 \mathrm{ml}$ of the dilution was aseptically inoculated onto the corresponding labelled petri plates. The sterilized nutrient agar and MacConkey agar were separately poured slowly into the base of the petri plate with slight swirling for uniform distribution of the medium. The plates were allowed to solidify and incubated at $37 \pm 2{ }^{\circ} \mathrm{C}$ for $24 \mathrm{hr}$ and distinct bacterial colonies in the plates were used to determine the total bacterial counts (TBC) and expressed as colony forming unit per millilitre of the test sample (cfu/ml) (Barrow \& Feltham, 2008 p. 60; Long et al., 2017).

\section{Identification and Characterization of Bacteria}

Following the culturing and Gram staining processes, three bacterial colonies were picked based on their different colonial characteristics and each of them was phenotypically characterized by performing basic biochemical tests such as catalase, indole, urease, oxidase, citrate, methyl red and Voges-Proskauer as prescribed standard methods (Adams \& Moss, 2008 p. 141; Barrow \& Feltham, 2008 p. 60).

\section{Statistical Analysis}

The statistical significance was performed using students $\mathrm{T}$ - test to compare the means of bacterial counts and one-way analysis of variance (ANOVA) was applied to determine the means of bacterial loads of different storage temperatures (Sokal \& Rohif, 1994 p. 945 ).

\section{RESULTS}

The mean viable sensory evaluation test carried out on both the boiled and raw eggs on daily basis from Day 1 to 46 revealed that; the boiled eggs at room temperature (BRT) started producing offensive odour from day 9 (4.7) while the bad odour of the boiled eggs at refrigerator temperature (BFT) started from day 16 (3.5). The raw eggs stored at room temperature (RRT) started developing unacceptable smell from day 26 (3.5) while the raw eggs stored in refrigerator temperature (RFT) began smelling from day 37 (3.0) (Tables 1a and b).

Table 1a Mean Sensory Evaluation of The Eggs Examined from Day 1 To Day 23

\begin{tabular}{|c|c|c|c|c|c|c|c|c|c|c|c|c|c|c|c|c|c|c|c|c|c|c|c|}
\hline \multirow{3}{*}{ Code of eggs } & \multicolumn{23}{|c|}{ DAY 1-23 } \\
\hline & 1 & 2 & 3 & 4 & 5 & 6 & 7 & 8 & 9 & 10 & 11 & 12 & 13 & 14 & 15 & 16 & 17 & 18 & 19 & 20 & 21 & 22 & 23 \\
\hline & \multicolumn{23}{|c|}{ Mean sensory evaluation $(\mathrm{k})$ on each day of storage } \\
\hline BRT & 5 & 5 & 5 & 5 & 5 & 5 & 5 & 5 & 4 & 4 & 3.5 & 3.5 & 3.3 & 3 & 3 & 2.3 & - & - & - & - & - & - & - \\
\hline BFT & 5 & 5 & 5 & 5 & 5 & 5 & 5 & 5 & 5 & 5 & 5 & 5 & 5 & 5 & 5 & 3.5 & 3.3 & 3.3 & 3.3 & 3 & 2 & - & - \\
\hline RRT & 5 & 5 & 5 & 5 & 5 & 5 & 5 & 5 & 5 & 5 & 5 & 5 & 5 & 5 & 5 & 5 & 5 & 5 & 5 & 5 & 5 & 5 & 5 \\
\hline RFT & 5 & 5 & 5 & 5 & 5 & 5 & 5 & 5 & 5 & 5 & 5 & 5 & 5 & 5 & 5 & 5 & 5 & 5 & 5 & 5 & 5 & 5 & 5 \\
\hline
\end{tabular}

Key: BRT - Boiled Room Temperature; BFT - Boiled Refrigerator Temperature; RRT - Raw Room Temperature; RFT - Raw Refrigerator Temperature

Table 1b Mean Sensory Evaluation of the Eggs Examined from Day 24 to Day 46

\begin{tabular}{|c|c|c|c|c|c|c|c|c|c|c|c|c|c|c|c|c|c|c|c|c|c|c|c|}
\hline \multirow{3}{*}{$\begin{array}{l}\text { Code } \\
\text { of eggs }\end{array}$} & \multicolumn{23}{|c|}{ DAY 24-46 } \\
\hline & 24 & 25 & 26 & 27 & 28 & 29 & 30 & 31 & 32 & 32 & 34 & 35 & 36 & 37 & 38 & 39 & 40 & 41 & 42 & 43 & 44 & 45 & 46 \\
\hline & \multicolumn{23}{|c|}{ Mean sensory evaluation $(\mathrm{k})$ on each day of storage } \\
\hline BRT & - & - & - & - & - & - & - & - & - & - & - & - & - & - & - & - & - & - & - & - & - & - & - \\
\hline BFT & - & - & - & - & - & - & - & - & - & - & - & - & - & - & - & - & - & - & - & - & - & - & - \\
\hline RRT & 5 & 5 & 3.5 & 3.7 & 3.7 & 3.7 & 3.7 & 3.3 & 3.3 & 3 & 3 & 2.3 & 1 & - & - & - & - & - & - & - & - & - & - \\
\hline RFT & 5 & 5 & 5 & 5 & 5 & 5 & 5 & 5 & 5 & 5 & 5 & 5 & 5 & 4 & 4.7 & 4.7 & 4.7 & 4.3 & 4.2 & 4.2 & 3 & 2 & 1 \\
\hline
\end{tabular}

ature; RFT - Raw Refrigerator Temperature

The bacterial load of the boiled egg stored at room temperature (BRT) determined at a 5- day interval showed that bacteria growth occurred in day 16 of storage with bacterial count ranging between $15 \times 10^{3}$ to $102 \times 10^{3} \mathrm{cfu} / \mathrm{ml}$ with higher bacterial count in the nutrient agar used. In the boiled eggs stored at the refrigerator temperature (BFT) the growth started at day 21 and the bacterial count ranged between $25 \times 10^{3}$ to $65 \times 10^{3} \mathrm{cfu} / \mathrm{m}$ (Table $2 \mathrm{a}$ ). However, no bacterial growth was observed from raw eggs stored at both room and refrigerator temperatures from day 6 to day 31. Prolonged storage of the raw eggs at room and refrigeration temperatures resulted in growth at day 36 and 46 respectively and ranged between $17 \times 10^{3}$ to $65 \times 10^{3}$ (Table $2 \mathrm{~b}$ ).

Table 2a Bacterial Analysis of Eggs In-Relation to Number of Days

\begin{tabular}{|c|c|c|c|c|c|c|c|c|c|c|c|c|c|c|c|c|c|c|c|c|c|c|c|c|c|c|c|c|c|c|}
\hline \multirow{3}{*}{$\begin{array}{l}\text { Code } \\
\text { of } \\
\text { eggs }\end{array}$} & \multicolumn{30}{|c|}{ Average counts of bacteria on eggs $\left(x 1^{3}\right)$} \\
\hline & \multicolumn{6}{|c|}{ DAY 6} & \multicolumn{6}{|c|}{ DAY 11} & \multicolumn{6}{|c|}{ DAY 16} & \multicolumn{6}{|c|}{ DAY 21} & \multicolumn{6}{|c|}{ DAY 26} \\
\hline & \multicolumn{3}{|c|}{ NA } & \multicolumn{3}{|c|}{ MA } & \multicolumn{3}{|c|}{ NA } & \multicolumn{3}{|c|}{ MA } & \multicolumn{3}{|l|}{ NA } & \multicolumn{3}{|c|}{ MA } & \multicolumn{3}{|c|}{ NA } & \multicolumn{3}{|c|}{ MA } & \multicolumn{3}{|c|}{ NA } & \multicolumn{3}{|c|}{ MA } \\
\hline BRT & 0 & 0 & 0 & 0 & 0 & 0 & 0 & 0 & 0 & 0 & 0 & 0 & 102 & 88 & 119 & 15 & 13 & 21.5 & 0 & 0 & 0 & 0 & 0 & 0 & 0 & 0 & 0 & 0 & 0 & 0 \\
\hline BFT & 0 & 0 & 0 & 0 & 0 & 0 & 0 & 0 & 0 & 0 & 0 & 0 & 4 & 3 & 1 & 0 & 0 & 0 & 51 & 65 & 58 & 60 & 25 & 60 & 0 & 0 & 0 & 0 & 0 & 0 \\
\hline RRT & - & - & - & - & - & - & - & - & - & - & - & - & - & - & - & - & - & - & - & - & - & - & - & - & - & - & - & - & - & - \\
\hline RFT & - & - & - & - & - & - & - & - & - & - & - & - & - & - & - & - & - & - & - & - & - & - & - & - & - & - & - & - & - & - \\
\hline
\end{tabular}

Table 2b Bacterial Analysis of Eggs In-Relation to Number of Days

\begin{tabular}{|c|c|c|c|c|c|c|c|c|c|c|c|c|c|c|c|c|c|c|c|c|c|c|c|c|}
\hline \multirow{3}{*}{ Code of eggs } & \multicolumn{24}{|c|}{ Average counts of bacteria on eggs $\left(x \mathbf{1 0}^{3}\right)$} \\
\hline & \multicolumn{6}{|c|}{ DAY 31} & \multicolumn{6}{|c|}{ DAY 36} & \multicolumn{6}{|c|}{ DAY 41} & \multicolumn{6}{|c|}{ DAY 46} \\
\hline & NA & & & M & & & NA & & & MA & & & $\mathrm{N} A$ & & & $\mathrm{M}$ & & & NA & & & MA & & \\
\hline BRT & - & - & - & - & - & & - & - & - & - & - & - & - & - & - & - & - & - & - & - & - & - & - & - \\
\hline BFT & - & - & - & - & - & & - & - & - & - & - & - & - & - & - & - & - & - & - & - & - & - & - & - \\
\hline RRT & 0 & 0 & 0 & 0 & 0 & 0 & 48 & 65 & 55 & 10 & 18 & 15 & 0 & 0 & 0 & 0 & 0 & 0 & 0 & 0 & 0 & 0 & 0 & 0 \\
\hline RFT & 0 & 0 & 0 & 0 & 0 & 0 & 0 & 0 & 0 & 0 & 0 & 0 & 0 & 0 & 0 & 0 & 0 & 0 & 42 & 40 & 40 & 40 & 65 & 50 \\
\hline
\end{tabular}

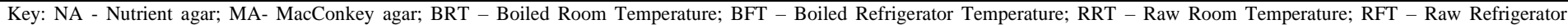
Temperature

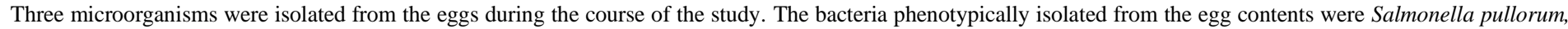

Proteus mirabilis and Pseudomonas sp. (Table 3). 
Table 3 Phenotypic Characterization of Microbial Isolates

\begin{tabular}{|c|c|c|c|c|}
\hline Characteristics & & Isolate 1 & Isolate 2 & Isolate 3 \\
\hline \multirow{4}{*}{ Cultural } & Elevation & Low convex & Swarming & convex \\
\hline & Margin & entire & Serrated & smooth \\
\hline & Shape & circular & circular & circular \\
\hline & Colour & grey & creamy & creamy \\
\hline \multirow{4}{*}{ Morphological } & Gram stain & - & - & - \\
\hline & Cell type & rod & rod & rod \\
\hline & Cell arrangement & single & single & single \\
\hline & Gram stain & - & - & - \\
\hline \multirow{11}{*}{ Biochemical } & Catalase & + & + & + \\
\hline & Indole & - & - & - \\
\hline & Urease & - & + & - \\
\hline & Oxidase & + & - & - \\
\hline & Methyl red & + & + & + \\
\hline & Voges Proskauer & - & - & - \\
\hline & Citrate & + & + & + \\
\hline & Acetate & - & - & - \\
\hline & Lactose & - & - & - \\
\hline & Mannitol & - & - & + \\
\hline & & Pseudomonas sp & Proteus mirabilis & Salmonella pullorum \\
\hline
\end{tabular}

Salmonella pullorum, Proteus mirabilis and Pseudomonas sp. Pseudomonas spp. were isolated from the raw eggs stored in the refrigerator. Proteus mirabilis was isolated from boiled eggs stored in both room and refrigerator temperature. While Salmonella pullorum was isolated from all the eggs stored. The Pseudomonas sp. was only isolated from raw eggs stored in the refrigerator temperature (RFT) while Proteus mirabilis was isolated from boiled eggs stored in both room and refrigerator temperature (BRT and BFT). However, Salmonella pullorum was isolated from both raw and boiled eggs stored in both room and refrigeration temperatures (BRT, BFT, RRT and RFT) (Table 4).

$\underline{\text { Table } 4}$ Occurrence of Isolated Bacterial in The Storage Temperatures

\begin{tabular}{lllll}
\hline Organism & BRT & BFT & RRT & RFT \\
\hline seudomonas spp & - & - & - & Present \\
Proteus sp mirabilis & Present & Present & - & - \\
Salmonella sp pullorum & Present & Present & Present & Present \\
\hline BRT - Boiled Room Temperture; & BFT - Boile & Refrigerator & Temperature; & RRT $-\mathrm{Raw}$
\end{tabular}

BRT - Boiled Room Temperature; BFT - Boiled Refrigerator Temperature; RRT - Raw Room Temperature; RFT - Raw Refrigerator Temperature; - - Not Present

Table 5a Analysis of Variance to Test for Significant Difference in Weight Eggs Stored at Various Storage Temperatures

\begin{tabular}{lccccc}
\hline $\begin{array}{l}\text { Source of } \\
\text { variation }\end{array}$ & $\begin{array}{c}\text { Degrees of } \\
\text { freedom }\end{array}$ & $\begin{array}{c}\text { Sum of } \\
\text { squares }\end{array}$ & $\begin{array}{c}\text { Mean } \\
\text { square }\end{array}$ & F & F 0.05 \\
\hline $\begin{array}{l}\text { Treatments } \\
\text { Residuals }\end{array}$ & 5 & 22.31 & 44.463 & 1.065 & 0.3853 \\
\hline
\end{tabular}

F-Calculated > F-critical, Ho is rejected (P < 0.05), Ho - No significant difference of the various weight of the boiled eggs stored at room temperature. On the other hand, the weight of boiled eggs stored in the refrigerator varied significantly at $\mathrm{P}<0.05$.

Table 5b Analysis of Variance to Test for Significant Difference in The Weight of The Boiled Eggs Stored in Refrigerator

\begin{tabular}{lccccc}
\hline $\begin{array}{l}\text { Source of } \\
\text { variation }\end{array}$ & $\begin{array}{c}\text { Degrees of } \\
\text { freedom }\end{array}$ & $\begin{array}{c}\text { Sum of } \\
\text { square } \\
\text { s }\end{array}$ & $\begin{array}{c}\text { Mean } \\
\text { square }\end{array}$ & F & F 0.05 \\
\hline Treatments & 5 & 1283.7 & 256.74 & 198.67 & $<0.05$ \\
Residuals & 120 & 155.08 & 1.292 & 19.67 & \\
\hline
\end{tabular}
significantly greater than expected by chance.

Table 5c Analysis of Variance to Test for Significant Difference in The Weight of The Raw Eggs Stored at Room Temperature

\begin{tabular}{lccccc}
\hline $\begin{array}{l}\text { Source of } \\
\text { variation }\end{array}$ & $\begin{array}{c}\text { Degrees of } \\
\text { freedom }\end{array}$ & $\begin{array}{c}\text { Sum of } \\
\text { squares }\end{array}$ & $\begin{array}{c}\text { Mean } \\
\text { square }\end{array}$ & F & $\begin{array}{c}\text { F } \\
\mathbf{0 . 0 5}\end{array}$ \\
\hline $\begin{array}{l}\text { Treatments } \\
\text { Residuals }\end{array}$ & 11 & 5388.5 & 489.86 & \multirow{2}{*}{12.220} & $<$ \\
\hline
\end{tabular}

The $\mathrm{P}$ value is $\mathrm{P}<0.05$, considered significant. Variation among column means is significantly greater than expected by chance.
Table 5d Analysis of Variance to Test for Significant Difference in The Weight of The Raw Eggs Stored in Refrigerator

\begin{tabular}{lcccccc}
\hline $\begin{array}{l}\text { Source of } \\
\text { variation }\end{array}$ & $\begin{array}{c}\text { Degrees of } \\
\text { freedom }\end{array}$ & $\begin{array}{c}\text { Sum of } \\
\text { squares }\end{array}$ & $\begin{array}{c}\text { Mean } \\
\text { square }\end{array}$ & F & $\begin{array}{c}\text { F } \\
\mathbf{0 . 0 5}\end{array}$ \\
\hline Treatments & 11 & 6497.4 & 590.4 & 316834 & $<0.05$ \\
Residuals & 264 & 0.4922 & 0.001864 & & \\
\hline $\begin{array}{l}\text { The P value is } \mathrm{P} \\
\text { significantly greater than expected by chance. }\end{array}$ & 0.05, considered & significant. & Variation among & column & means is \\
\end{tabular}

\section{DISCUSSION}

The eggs in the refrigerator maintained a relatively higher sensory quality than the eggs stored at room temperature. Storage of eggs at room temperature for few days was enough to substantially reduce the consumption quality of the eggs. The changes in the eggs standard may be as a result of differences in physicochemical composition of the eggs contents such as the albumen $\mathrm{pH}$, yolk index and percentage weight loss. The sensory quality of the eggs also reduced as the storage duration decreased. The bacterial load of the boiled egg stored at room temperature (BRT) determined at a 5- day interval showed that the bacteria growth occurred in day 16 of storage with bacterial count ranging from 15 to 102 $\times 10^{3} \mathrm{cfu} / \mathrm{ml}$ with higher bacterial count in nutrient agar (NA). In the boiled eggs stored at the refrigerator temperature (BFT), the growth was observed at day 21 and the bacterial count ranged from 25 to $65 \times 10^{3} \mathrm{cfu} / \mathrm{ml}$. However, no bacterial growth was observed from the raw eggs stored at both room and refrigerator temperatures from day 6 to day 31. Prolonged storage of the raw eggs at room and refrigeration temperatures resulted in growth at day 36 and 46 respectively and ranged from 1.7 to $6.5 \times 10^{3}$ (Tables $2 \mathrm{a}$ and $2 \mathrm{~b}$ ). The above results demonstrated that, a higher bacterial count was recorded in raw eggs kept in room temperature than in refrigeration temperature. This goes to show that refrigeration temperature extends the shelf life of both raw and boiled eggs.

The bacteria isolates identified in this study are pathogenic to humans and possess the capacity to persist on and in the egg for a longer period under harsh environmental conditions. This supports the reports of Dereu et al. (2005) and Jones et al. (1995), that microorganisms can be found on the outside of egg shell as a result of the egg emerging from the hen's body through the same route the faeces-containing bacteria is excreted leading to faecal contamination. Microorganisms inside a non-cracked or whole egg may be due to the presence of pathogens within the hen's oviduct before the shell forms around yolk and albumen. Different researchers have indicated that the transovarian route is the most important route for Salmonella sp. contaminating egg. This is due to the ability of the Salmonella sp. to colonize the ovary and oviduct (vertical transmission) of laying hens for a long time. In the penetration through the egg shell (horizontal transmission), the eggs pass through the highly contaminated cloaca area at the point of lay leading to visible faecal contamination on the shell. Eventually, the shell acquires contamination and being wet, the egg cools down immediately with the egg content contracting and a negative pressure is established inside egg content, thereby moving the bacteria through the cell (Radowski, 1995). However, some factors enhancing bacterial infection of eggs 
include physical chemical defence mechanisms that protect egg contact from invasion and multiplication. The egg shell and membrane physically hinder bacterial penetration into the egg albumen, while the vitellin membrane and chalazae reduce invasion into the nutritious component of the egg. The antimicrobial properties of the egg albumen (ovotransferin and avidin: chelating metal ions and biotin respectively) its viscosity and alkaline $\mathrm{pH}$ inhibit bacterial growth and egg yolk attack (Long et al., 2017; Moore \& Madden, 1993).

Adams and Moss, (2008) notes that the most common egg spoilage bacterial genera are the Salmonella, Escherichia, Pseudomonas, Aeromonas and Proteus (p. 141). This indicates that the gram-negative bacteria are well equipped to suppress or overcome the antimicrobial defences of the egg. This has now been supported by the outcome of this study with the presence of Salmonella sp. in all the samples of both boiled and raw eggs stored in room and refrigeration temperatures. The genus Proteus; was recorded in boiled room temperature (BRT) and boiled refrigeration temperature (BRT) while the Pseudomonas sp. was present only in the raw refrigeration temperature (RFT) (Table 4). Consequently, the eggs stored under refrigeration temperature presented $(\mathrm{p}<$ 0.05 ) when compared with eggs kept at room temperature. It was apparently evidenced that the quality of eggs changes significantly $(p>0.05)$ according to the storage temperature and period of storage mainly due to weight loss and internal and external infections by the bacteria. However, it is worthy of note that once eggs have been refrigerated, they must be kept refrigerated to prevent condensation from forming on the shell. If they warm up, the moisture makes it easier for bacteria to penetrate the shell.

\section{CONCLUSION}

The mean total viable count for eggs stored at room temperature was higher than refrigeration storage temperature, as bacterial growth may partly be due to handling, storage equipment and immediate environmental conditions of the storage room. Therefore, consumers should be encouraged to store eggs in refrigerators and maintain good sanitary practices to reduce contamination. More so, the isolated bacteria being pathogenic organisms, would necessitate adequate cooking eggs before consumption and places where eggs are stored should be of satisfactory hygienic standard to reduce bacterial contacts. The practice of eggs undergoing a sterilizing process before they are sold like washing in hot, soapy water and sprayed with a disinfectant, which kills any bacteria on the shell should be encouraged.

Acknowledgment: The authors express their profound gratitude to the department of biological sciences, college of natural and applied sciences, Igbinedion University, Okada, Nigeria, for the enabling environment and funding of this research study.

\section{REFERENCES}

Adams, M.R., \& Moss, M.O. (2008). Food Microbiology ( $3^{\text {rd }}$ ed.). The Royal Society of Chemistry. https://doi.org/10.1039/9781847557940

Barnhart, H.M., Dreesen, D.W., Bastien, R., \& Pancorbo, O.C. (1991). Prevalence of Salmonella Enteritidis In Eggs, Cloacal Swab Specimens and Other Serovars In Ovaries of Layer Hens at Time of Slaughter. Journal of food protection, 54,488 - 49. . https://doi.org/10.4315/0362-028x-54.7.488

Barrow. I., \& Feltham, R.K.A. (2008). Cowan and Steel's Manual for The Investigation of Medical Bacteria ( ${ }^{\text {rd }}$ ed.) Cambridge University Press. https://doi.org/10.1017/CBO9780511527104

Davies, R.J., \& Breslin, M. (2002). Investigation of Salmonella Contamination and Disinfection in Farm Egg-Packing Plants. Journal of Applied Microbiology, 94, 191 - 196. https://doi.org/10.1046/j.1365-2672.2003.01817.x

Dereu, K., Grigpedth, K.I., Uytededlle, U.M., \& Helman, 1. C. (2005). The Use of Total Aerobic and Gram-Negative Bacteria for Quality Assurance in The Production Chain of Consumption Eggs. Journal of Poultry Science, 46, 149 157. https://doi.org/10.1016/j.foodcont.2004.01.004

Jones, F.T., Rives, D., \& Carey, S.K. (1995). Salmonella Contamination in Commercial Eggs and Egg Production Facility. Journal of Poultry Science, 7(4), 753 -757. https://doi.org/10.3382/ps.0740753

Long, M., Yu, H., Chen, L.,Wu, G., Zhao, S., Deng, W., Chen, S., Zhou, K., Liu, S., He, L., Ao, X., Yan, Y., Ma, M., Wang, H., Davis, M.A., Jones, L., Li, B., Zhang, A., \& Zou, L. (2017). Recovery of Salmonella isolated from eggs and the commercial layer farms. Gut Pathog., 9, 74. https://doi.org/10.1186/s13099-017$\underline{0223-8}$
Moore, J. K., \& Madden, R. (1993). Detection and Incidence of Listeria Species in Blended Raw Eggs. Journal of Food Protection, 65, 52 - 60. https://doi.org/10.4315/0362-028x-56.8.652

Padron, M.N. (2005). Egg Dipping in Hydrogen Peroxide Solution to Eliminate Salmonella typhimurium from Egg Shell Membranes. Journal of Avian Diseases, 39, 127 - 134. https://doi.org/10.2307/1591818

Radowski, M.J. (19955). Occurrence of Escherichia coli in Consumption Eggs in Poland. International Journal of Food Science, 4(1), 161 - 167. https://doi.org/10.1016/S0168-1605(00)00420-7

Sokal, R.R., \& Rohif, F. Y. (1994). The Principle and Practice of Statistics in Biological Research. ( $3^{\text {rd }}$ ed). W.H Freeman Publishers. Pp 945. https://www.amazon.com/Biometry-Principles-Statistics-Biological-1994-0101/dp/B01FIWNPYC 